\title{
EFFECTS OF PARASITISM ON THE PRODUCTION AND PRODUCTIVITY OF CAGED OREOCHROMIS NILOTICUS IN WINAM GULF OF L. VICTORIA
}

\author{
Steve Omari Ngodhe, Emmy Kerich* and Kiptoo Kipkorir \\ University of Eldoret P.O Box 1125-30100 Eldoret \\ *Corresponding Authors Email Address: emmycheptoo@gmail.com
}

\section{Cite this article:}

Ngodhe S.O., Kerich E., Kipkorir K. (2021), Effects of Parasitism on the Production and Productivity of caged Oreochromis niloticus in Winam Gulf of L. Victoria. African Journal of Environment and Natural Science Research 4(4), 99108. DOI: 10.52589/AJENSRMWGUYD8Q.

\section{Manuscript History}

Received: 15 Sept 2021

Accepted: 30 Sept 2021

Published:28 Oct 2021

Copyright $\odot 2020$ The Author(s). This is an Open Access article distributed under the terms of Creative Commons Attribution-NonCommercialNoDerivatives 4.0 International (CC BY-NC-ND 4.0), which permits anyone to share, use, reproduce and redistribute in any medium, provided the original author and source are credited.
ABSTRACT: The general objective of this study was to assess the effects of parasitism on the production and productivity of caged Oreochromis niloticus in Winam Gulf of L. Victoria. With the need to increase food production through fish products amid overfishing and pollution stress in the lake, cage farming is seen to have the potential to bridge the fish supply and demand gap continues to widen. Cage culture is a new technology in the offing that needs to be explored to justify its potential. Fish parasites are always a threat in an enclosed culture system and because of this, it is necessary to assess their effects on fish condition factors before recommendation. It is because of this reason that a total of 480 caged Oreochromis niloticus were purchased and examined for parasites using the recommended procedures for parasitological analysis. The class Trematoda which included seven taxa were found to be the most common and prevalent parasites in cages of the Winam Gulf. This was attributed to the presence of piscivorous birds which are definitive hosts seen more often around the culture systems and also overstocking observed and reported during the study period which increases the spread and transmission of parasites from one fish to another. Despite the prevalence, infestation did not affect the fish condition factor in all the study areas as the majority of infected fish recorded between good and excellent body condition factors. This was due to low mean intensities recorded and a shorter period of exposure to parasitic infestation as most farmers were barely 3 years into the system. In conclusion, for the government to explore the blue economy and achieve the Vision 2030 and SDGs on food security and poverty reduction by 2030, efforts to promote commercial cage culture enterprises in the Winam Gulf must be bolstered, provided that cages are located in deep waters with low concentrations in specific areas and low stocking densities to avoid compromising the environment.

KEYWORDS: Effects, Parasitism, Oreochromis niloticus, Productivity, Winam-Gulf 


\section{INTRODUCTION AND BACKGROUND}

Aquaculture is a rapidly growing mode of food production worldwide. At the moment, fish farming accounts for more than a quarter of all fish consumed directly by humans, employing approximately 220 finfish and shellfish species. Africa's contribution to aquaculture production is negligible in comparison to the rest of the world (FAO, 2007). Aquaculture is a relatively new industry with a lot of growth potential. The majority of domesticated species are not significantly different from their wild counterparts, nor have they been extensively domesticated (Mbugua, 2008). Aquaculture innovation provides farmers with a higher rate of return on investment than traditional farming practices, and it can also be a natural way to manage aquaculture production to become more sustainable.

Commercial aquaculture is yet to gain popularity in the developing world (Quagrainie et. al., 2009).

This is because it is commonly established that severe weather conditions and pest and disease outbreaks create huge variations in output yield in aquaculture and fisheries businesses. In the empirical research of business behaviour and productivity change, risk-averse producers choose input levels that are lower than optimal input levels for risk-neutral producers. When adopting new technologies, risk-averse producers may not choose the technology with the highest mean output because they are concerned about risk attributes (Oladele and Fawole, 2007).

The Kenya Vision 2030 envisions transforming Kenya into a newly industrialized middleincome country by 2030, offering a high quality of life for all Kenyans (FAO, 2016). Between 2009 and 2013, the Kenyan government invested 70 million dollars in fish farming for food security under the social-economic pillar of Vision 2030. Under the Kenya Economic Stimulus Programme (FAO, 2016) whose aim was to jumpstart the Kenyan economy towards long-term growth and development, the Ministry of Fisheries and Development launched a fish farming project, themed around - Improving nutrition and creating over 120,000 jobs and income opportunities has been one of the more successful components. In Kenya, the cage and pond culture systems are probably the latest and most developed system and information on the occurrence, prevalence and pathogenicity of fish parasites and diseases are very essential. Such information enables aquaculturists to apply correct control measures for fish diseases which reduce the cost of production and increase the productivity which has not been attained to date.

Some of the fish parasites are zoonotic and they include helminths such as anisakid nematodes Anisakis simplex; Pseudoterranova decipiens, cestodes of the genus Diphyllobothrium spps. and digenetic trematodes of the families Heterophyidae, Opisthorchiidae and Nanophyetidae (Adams et al., 1997; Noga, 2010; Robert, 2012). Factors associated with zoonotic helminths include feeding animal reservoir hosts (dogs, cats, pigs, chicken, ducks) with live infested fish, humans feeding on undercooked or raw fish and handling infested fish (Noga, 2010). The presence of snails and the addition of green vegetation from other farms have also been listed as risk factors (Phan et al., 2010). The snails (families Thiaridae and Bithynidae) act as intermediate hosts for fish-borne zoonotic trematodes (FZT) while the vegetation could contaminate the ponds with FZT eggs from other farms (Clausen et al., 2012). Various factors including the length of the host, size, parasites intensity and prevalence, environmental variables, such as size, shape and type of water body, temperature, salinity, oxygen content and pH have been shown to affect parasitism in fish (State and State, 2009; Lagrue et al., 2011; Ali 
et al., 2014). These need to be investigated to document factors that contribute to low aquaculture productivity in Kenya and are most likely to threaten the achievement of the country's Vision 2030 on food security and poverty alleviation.

According to FAO (2010), global demand for fish has increased while the supply of freshwater fish from catch fisheries has decreased. As global fish catches drop and the population grows, aquaculture has enormous potential for expansion in Kenya to produce crucial amounts of fish to cover the rising gap between national fish supply, demand, and food security as indicated in Vision 2030. Due to the Economic Stimulus Programme (ESP), commercial fish farming in Kenya (FAO, 2016). The success of this new government project re-energized Kenyan freshwater fish farming. Aquaculture activities are capable of creating an industry employing and supporting a substantial number of fish farmers, feed manufactures, fish processors, traders and other actors. Hecht \& Endemann (1998) reported that one of the major constraints observed to hold back productivity in fish farming includes parasites and diseases. Therefore, to achieve a highly productive and profitable venture, all the constraints faced in aquaculture must be addressed. Information on the occurrence, prevalence and pathogenicity of fish parasites and diseases is essential in aquaculture. Such information enables aquaculturists to apply correct control measures for fish diseases to reduce the cost of production, and period of growth, thereby increasing the profit margins (Akoll et. al., 2012).

\section{MATERIALS AND METHODS}

\section{Study Area}

Winam Gulf is a $1400 \mathrm{~km} 2$ bay with a $550 \mathrm{~km}$ shoreline in northeastern Kenya (Fig. 1). The 3 $\mathrm{km}$ wide Rusinga waterway connects it to the main basin. A causeway completed in 1980 closed an even narrower but deeper channel south of Rusinga Island. The Winam Gulf averages $6 \mathrm{~m}$ and $68 \mathrm{~m}$ deep. Aux physico-chimiques, the Winam Gulf is unlike the main basin's pelagic zone.

These four major rivers contribute $37.6 \%$ of all surface water input into Lake Victoria, including considerable amounts of terrigenous elements. The Winam Gulf area is heavily farmed and fertilized. The main growing seasons are December-February and July-September. The gulf's sedimentation and nutrient content have risen in recent decades due to land degradation, surface runoff, and soil erosion, although an increase in air deposition is still debated (Gordon et al., 2009) 


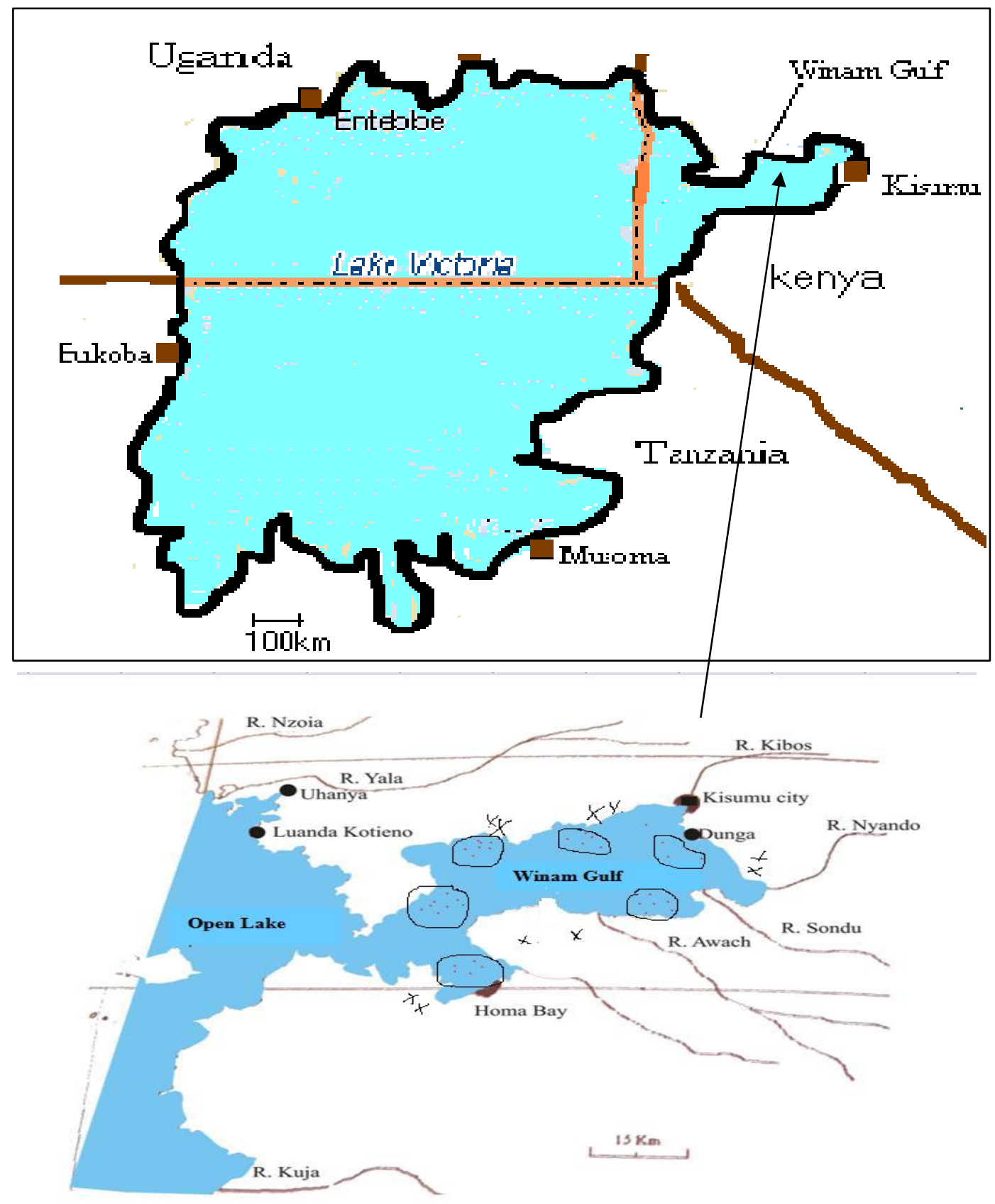

Fig 1. Map showing how cages are distributed within Winam Gulf of L. Victoria NB: Dotted areas indicate the cage distribution within the gulf 


\section{Sampling procedure}

Cages were lifted and hand nets were used to scoop the fish from the cage for parasitological analysis. A total of 480 samples of different sizes were analyzed from various cages distributed within the Winam-Gulf of L. Victoria, Kenya. Fish morphometrics (Measuring of total length and weight) before dissection and observation of external fish condition was done. Standard dissection procedures (protocols) in Aloo et al. (2004) and identification keys by Paperna (1996) were employed in the laboratory to study parasitic infections and diseases. The measured total weight $(\mathrm{g})$ and total length $(\mathrm{cm})$, was then used to determine Fulton's condition factor as follows:

$$
K_{\text {factor }}=\frac{100 W}{L^{3}}
$$

Where

$W=W=$ Weight

$L=L \quad=$ Length

\section{Parasitological Examination}

Parasitological examinations were performed in accordance with conventional necropsy procedures (Thoesen, 1994). Internal inspections were performed by extending the intestines and stomach in a petri dish and then cutting them open longitudinally. The contents were examined at a magnification of X100 using a compound microscope. Internal organs were also inspected using a compound microscope by removing a little portion from each, placing it on a glass slide, squashing it with a coverslip, and observing it under a compound microscope. Metacercariae of trematodes were released from their cysts for better examination by teasing them out of the membranous coat. All parasites observed were counted, identified and recorded. Isolated parasites were fixed and stored in $70 \%$ alcohol and preserved in 10\% formalin (Paperna, 1996) for identification. Staining and mounting of parasite specimens were done by procedures described by Pritchard and Kruse (1982). Specimens were then passed through a graded series of concentrations of alcohol from 70,50,35\% and finally in distilled water to bring them to the level of the stain. They were stained using Mayer's hematoxylin stain then dehydrated through a series of graded alcohol concentrations of 35, 50, 70, 85, 95 and absolute alcohol. Clearing of specimens was done with xylene after which they were mounted on glycerin. Further identification of parasites was done by use of morphological features and identification keys described by Paperna (1996) and Khalil et al., (1994). 
a) Parasite Prevalence Rates

Prevalence levels of tilapia parasites were quantified according to Bush et al., (1997) as follows:

$$
\text { Prevalence }=\frac{\begin{array}{c}
\text { Number of hosts infected with one or more individuals } \\
\text { of a particular parasite species or taxonomic group }
\end{array}}{\text { number of hosts examined for that parasite }} \times 100
$$

b) Mean Intensity Levels of Parasites

Mean intensity (MI) of parasites was determined according to Bush et al., (1997) as follows:

$$
M I=\frac{\text { Total number of individuals of a particular parasite species }}{\text { number of hosts infected with that parasite }}
$$

\section{Data analysis}

A non-parametric sign test was used during analysis to test variations in parasite prevalence, diversity and intensity in various cages. Student ${ }^{\text {ee }} \mathrm{t}$-test was used in determining whether the differences obtained in mean prevalence and mean intensities in cages conditions were statistically significant. Analysis of variance (ANOVA) was used to determine the effect of parasitism on fish condition factors and general growth. The relationship between the fish size and the parasite mean intensity was done by a simple correlation analysis

\section{RESULTS AND DISCUSSION}

\section{Effects of Parasitism on Condition Factor}

The effect of parasitic infection on the condition factor of fish was influenced by different culture systems (Table 1). In cages, parasitic infection was mostly associated with higher condition factors of fish than in ponds and wild. Datylogyrus ssp. $(\mathrm{F}=5.197, \mathrm{p}=0.085)$, Tylodelphys ssp. $(\mathrm{F}=8.181 ; \mathrm{p}=0.149)$, Diplostomum ssp. $(\mathrm{F}=24.691 ; \mathrm{p}=0.042)$ and Trichodina ssp. $(\mathrm{F}=3.281 ; \mathrm{p}=0.144)$. Only Diplostomum ssp. had a very slight significant effect on fish condition factors in cages (Table 1).

Results for the length-weight relationship showed that $O$. niloticus recorded positive allometric growth $(b>3)$ in all the cages sampled (Fig 2). The value of the regression slope $b$ recorded was 3.09 (Fig. 1) 
African Journal of Environment and Natural Science Research

ISSN: 2689-9434

Volume 4, Issue 4, 2021 (pp. 99-108)

www.abjournals.org

Table 1: ANOVA Table showing the effect of parasitism on condition factor of $O$. niloticus in Cage $(\mathrm{p}=\mathbf{0 . 0 5})$.

Dactylogyrus Tylodelphys Diplostomum Trichodina Amirthalingamia Acanthocestis

\section{Cage}

$\begin{array}{lllll}\text { F } & 5.197 & 8.181 & 24.691^{*} & 3.281\end{array}$

$\begin{array}{lllll}\mathrm{p} & 0.085 & 0.149 & 0.042 & 0.144\end{array}$

\section{Cage}

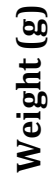

$\mathrm{y}=0.019 \mathrm{x}^{3.09}$

$\mathrm{R}^{2}=0.984$

Total Length $(\mathrm{Cm})$

Fig. 2. Length-Weight Relationship of Oreochromis niloticus in cages of Winam Gulf of L. Victoria 

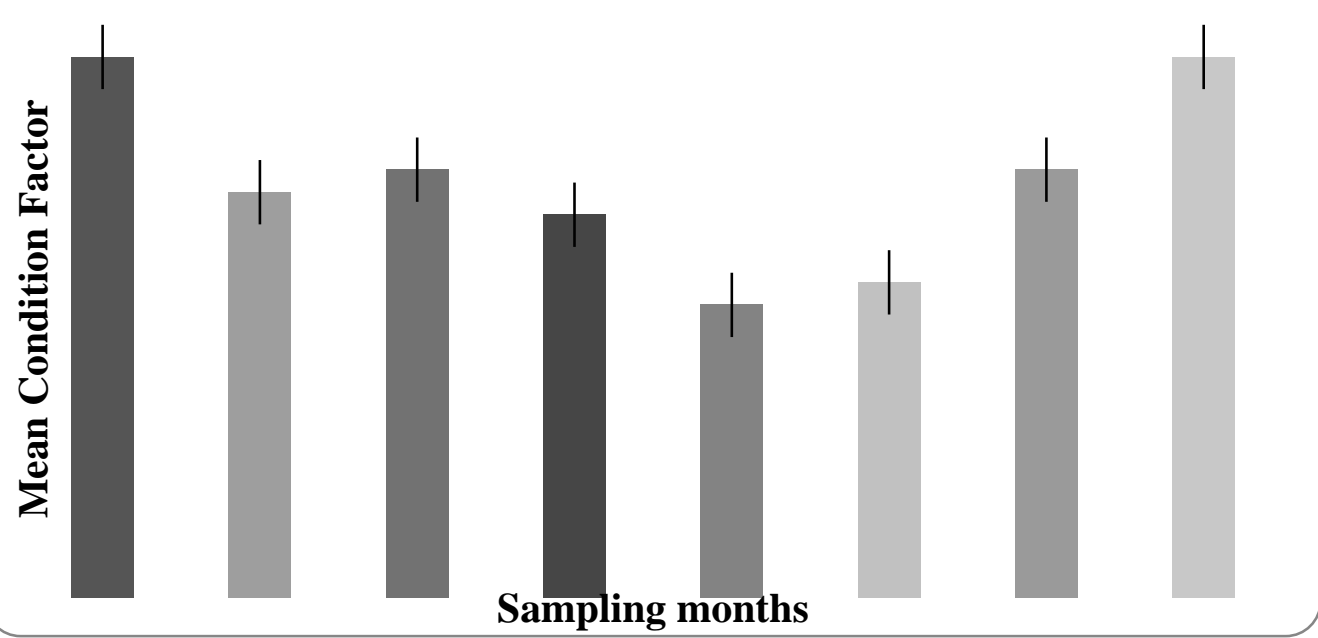

Fig. 3. Shows the mean monthly condition factor of fish during the study period

In the present study, most infected fish were in good, excellent and fair body conditions. None of the infected fish had poor body condition (Fig. 3). The analysis of variance showed that the differences in body conditions among the infested fish were not statistically significant $(\mathrm{P}>0.05)$. This shows the infestation was low and had minimal effect on the fish's body condition. This could be because of the intensity of the low parasite recorded. The lengthWeight relationship also confirms this (Fig. 2) and in some instances, fish that were infected with trematodes such as Gyrodatylus spp., Datylogyrus spp., Tylodelphys spp. and Diplostomum spp. had a higher condition factor than un-infected ones. This study is in agreement with the study by Polacic et al., (2009) who revealed that parasitic infection can either result in poor or good body condition depending on various factors for instance they further indicated that an increase in food availability enhances the fish immune system, hence resistance to diseases and high condition factor. Another study by Skarstein et al., 2001 revealed that parasite infection can sometimes lead to better condition factors and fast growth. This is a result of an increase in the weight of body organs such as the spleen and gonads. When these organs become larger and bigger, they affect weight which is a variable in calculating the condition factor. Parasites also make fish reduce their biological activity and increase food intake to cope with the situation. All these increases the growth rate and the condition factor of the infected fish and in some instances, a better condition factor than the uninfected ones. When access to food is restricted like in the case of cage and pond systems, infected fish are able to sustain high growth rates, fuel parasite growth, and still lay down energy reserves. Skarstein et al., 2001 further indicated that trematodes parasites reduces the weight of the liver and causes slow growth in infected fish. These could be the reasons why fish (infected and uninfected) showed a mixed condition factor which ranged from good to excellent. Despite visible lesions caused by different groups of parasites, the presence of the parasites did not seem to affect the body condition of their host. Ndeda (2013) also showed that the presence of parasites did not affect the condition factor of fish in culture systems when their mean intensity is low. 
It can therefore be concluded that parasites at their initial stages of infection do not have a negative impact on fish production and productivity in cages and the study recommends the use of cage production with average stocking density in deep waters with the regular water quality monitoring and action be taken should there be any compromise in water quality.

\section{Acknowledgement}

The authors like to express their gratitude to the University of Eldoret in Kenya for providing laboratory and technical assistance. Additionally, we would like to express our appreciation to the National Research Fund (NRF) for its financial support.

\section{REFERENCES}

Adams, A.M., Murrell, K.D. and Cross, J.H. (1997). Parasites of fish and risks to public health. Scientific and Technical Review of the Office (Rev.sci.tech.Epiz) 16(2): 652-660.

Akoll, P., Konecny, R., Mwanja, W. and Schiemer, F. (2012). Role of parasites in viral and bacterial infections. Aquaculture 356-357: 123-127.

Ali, A., Hayat, S., Ahmed, M.S., Elahi, N., Saghir, A., Ali, H. and Khan, W.A. (2014). Prevalence of Lernaeid Ectoparasites in some Culturable Fish species from different Nurseries of Punjab. Biologia (Pakistan) 60(1): 123-127.

Aloo, P.A., Anam, R.O., and Mwangi, J.N. (2004). Metazoan parasites of some commercially important fish along the Kenyan Coast, Western Indian Ocean. J. Mar. Sci., 3: 77-78.

Clausen, J. H., Madsen, H., Murrell, K. D., Van, P. T., Nguyen, H., Thu, T., Do, D. T., Anh, L., Thi, N., Manh, H. N. and Dalsgaard, A. (2012). Prevention and Control of Fishborne Zoonotic Trematodes in Fish. Emerging infectious diseases 18(9): 1438-1445.

FAO (2007). Aquaculture in Kenya: Status, Challenges and Opportunities, Fishery Country Profile FID/CP/KEN, http:/www.researchintouse.com. accessed on 7/04/2011

FAO (2016). Fisheries and Aquaculture Department. Fishery and Aquaculture Country Profiles. The Republic of Kenya. pp. 1-28

FAO, (2010): Capture Production 1950-2008: FAO Fisheries Department, Fishery Information, Data and Statistics Unit. Food and Agriculture Organization of the United Nations, Rome.

Hecht, T., Endemann, F. (1998). The impact of parasites, infections and diseases on the development of aquaculture in Sub-Saharan Africa, J. Appl. Ichthyol., 14: 213-221.

Khalil, L., Jones, A., \& Bray, R. (. (1994). Keys to the cestode parasites of vertebrates. Wallingford: CAB International.

Lagrue, C., Kelly, D.W., Hicks, A. and Poulin, R. (2011). Factors influencing infection patterns of trophically transmitted parasites among a fish community: host diet, hostparasite compatibility or both ?. Fish biology 79: 466-485.

Mbugua H.M. (2008) A Comparative Economic Evaluation of Farming of Three Important Aquaculture Species In Kenya. Blackwell Publishing, United Kingdom.

Ndeda, V. M. (2013). Effect of Diplostomum species on the length-weight relationship of farmed Nile tilapia in Kibos is Kisumu city, Kenya. Fisheries and Aquaculture Journal, $60,1-7$. 
Noga, E.J. (2010) Fish Disease: Diagnosis and Treatment. second Edition. Edited by E. J. Noga. Wiley-Blackbell, West Sussex UK: 538pp.

Paperna, I. (1996). Parasites, infections and diseases of fishes in Africa: An update. CIFA Technical paper FAO, No. 31, Rome, Italy.

Phan, V.T., Ersbøll, A.K., Nguyen, K.V., Madsen, H. and Dalsgaard, A. (2010). Farm-Level Risk Factors for Fish-Borne Zoonotic Trematode Infection in Integrated Small-Scale Fish Farms in Northern Vietnam. PLoS Neglected Tropical Diseases 4(7): 1-9.

Polac` ic, M.; Jana' c`, M.; Jurajda, P.; Ada'mek, Z.; Ondrac`kova', M.; Trichkova, T.; Vassilev, M., 2009: Invasive gobies in the Danube: invasion success facilitated by availability and selection of superior food resources. Ecol. Freshw. Fish. 18, 640-649.

Pritchard, M., \& Kruse, G. (1982). The collection and preservation of animal parasites. 6th edition. . Lincoln: University of Nebraska Press.

Quagrainie, K. K., Amisah, S., and Ngugi, C. C. (2009). Aquaculture information sources for Robert, J.R. (2012) Fish Pathology. Fourth Edition. Edited by J. R. Robert. Wiley-Blackbell, West Sussex UK. pp. 292-338.

Skarstein F, Folstad I, Liljedal S (2001) whether to reproduce or not: immune suppression and costs of parasites during reproduction in the Arctic char. Can J Zool 79:271-278 small-scale fish farmers: the case of Ghana. Aquaculture Research, 40(13), 1516-1522.

State, E. and State, A.I. (2009). Parasite Assemblages in Fish Hosts. Bio-Research 7 (2): 561-70.

Thoesen, J. (1994). Suggested procedures for the detection and identification of certain finfish and shellfish pathogens. 4th edition Version 1. (J. Thoesen, Ed.) Bethesda, Maryland: 